\section{Andrzej Hanusik}

(iD) https://orcid.org/0000-0001-9696-7344

Department of Transport

Faculty of Economy

University of Economics in Katowice,

Katowice, Poland

andrzej.hanusik@ue.katowice.pl

\section{Anna Woźnica}

(iD) https://orcid.org/0000-0003-3910-9743

Department of Transport

Faculty of Economy

University of Economics in Katowice,

Katowice, Poland

anna.woznica@ue.katowice.pl

\title{
Strategic analysis for Poland as a European hub for Belt and Road Initiative
}

Accepted by Editor Ewa Ziemba | Received: October 13, 2020 | Revised: February 3, 2021; February 18, 2021 | Accepted: March 1, 2021 | Published: March 16, 2021.

(C) 2021 Author(s). This article is licensed under the Creative Commons Attribution-NonCommercial 4.0 license (https://creativecommons.org/licenses/by-nc/4.0/)

\begin{abstract}
Aim/purpose - This paper aims at determining the role of Poland in the Belt and Road Initiative (BRI) and identifying an alternative course of the trail. However, there are still many variables that can significantly affect the extent of Poland's participation in BRI.

Design/methodology/approach - The paper was based on a literature query and interviews with six experts of the Polish logistics environment closely connected to the concept of the New Silk Road. The interviews and the literature analysis allowed of the authors to define potential scenarios for the course of the New Silk Road. In addition, the SWOT analysis was used to identify the Poland's role in BRI.

Findings - The most important factors that can significantly contribute to Poland's participation in BRI are a very convenient geographical location and a strong logistics sector, whereas the main negative factors are the ambivalent attitude of the Polish authorities towards the Chinese party and the underdeveloped modern railway infrastructure. The study identified some potential scenarios for the route of the New Silk Road, i.e., Poland as a European hub, transit only, southern road and northern road (ro-ro neighbors). The first scenario is the most favorable for Poland - Poland as a European hub. This is due to the current course of the New Silk Road and the location of Poland on the most economically effective transport corridor.

Research implications/limitations - The research findings allow for a relatively precise definition of possible scenarios of the BRI Northern Corridor through areas directly related to Poland. The results may contribute to raising knowledge and awareness about BRI, which may provide insights into an academic and social debate on this topic. The upshot is that the results may entail actual activities contributing to increasing the chances of Poland for being a European hub gate for BRI.
\end{abstract}

Cite as: Hanusik, A., Woźnica, A. (2021). Strategic analysis for Poland as a European hub for Belt and Road Initiative. Journal of Economics \& Management, 43, 90-109. https:/doi.org/10.22367/jem.2021.43.05 
Originality/value/contribution - Previous publications explored various route alternatives of the entire New Silk Road, whereas there was no analysis of the last stage of the transport corridor on which Poland lies. The paper is a response to this research gap.

Keywords: Belt and Road Initiative, New Silk Road, Northern Corridor, logistics, international trade.

JEL Classification: E27, E61, F15.

\section{Introduction}

The New Silk Road is one of the most extensive business ventures of the $21^{\text {st }}$ century - this initiative will increase global GDP by USD 7.1 trillion per year by 2040 (Tuttle, 2019). Currently, Poland is located on one of the main Belt and Road Initiative (BRI) corridors, which makes this initiative very important for the country's economy.

There are many studies describing the BRI environmental and social impacts (Hughes et al., 2020), its role in the global economy (Cai, 2017), political conditions that directly or indirectly may influence this project (Lei, 2018; Murton \& Austin, 2020), or BRI financing aspects (Summers, 2020). To the authors' knowledge, there are some research papers referring to the role of Poland in this initiative (Choroś-Mrozowska, 2019), but none of them described potential scenarios for the development of this concept. Furthermore, some of the available international sources mention Poland and as a rule, they treat it as a small part of the entire study (Prodi \& Fardella, 2018). Therefore, it is necessary to fill this research gap. More importantly, this research gap is also visible for the private sector, on the initiative of which projects are created to increase the importance of Poland in this initiative, e.g., "Railway for Poland" implemented by Polish Supply Management Leader (2021).

The purpose of this paper is to determine the role of Poland in BRI. Two main research questions were asked:

1. Does Poland have strengths necessary to claim the role of European Hub Gate for Belt and Road Initiative?

2. Are there any other routes along the Northern BRI corridor that could be an alternative for Poland?

The paper presents the basic information about BRI and how these issues are tackled in the existing scientific literature. Moreover, the study identifies possible scenarios for the transport corridors directly through Poland (both as the Main European Hub and a strictly transit country) as well as those that may 
prove to bring a competitive advantage. The paper ends with a synthetic summary of obtained results and an overview of the state of current knowledge, further research possibilities as well as research implications for management and policy-makers.

\section{Literature review}

BRI directly refers to the ancient Silk Road that connected China and other Asian countries with Europe (primarily the Byzantine Empire and Venice) (Kuzmina \& Mair, 2008). The first mention of the Silk Road restoration (then as a platform for cooperation between Asian countries) dates back to the late twentieth century, while the official inauguration of activities aimed at creating a new version of this route was held in 2013 during the autumn visit of the President of the People's Republic of China, Xi Jinping, in Kazakhstan (Wang, Lim, Zhang, Zhao, \& Lee, 2020).

One of the BRI aspects is the development of a network of transport corridors connecting China with Asian, African and European countries (Garcia-Herrero \& Jianwei, 2017). However, the significance, scope and purpose of the initiative are much broader. The assumption is to be a network of wide range of connections (e.g., commercial, economic, political, cultural), a kind of cooperation platform between the countries involved. Therefore, BRI is a kind of economic corridor, not attached to a specific transport route because there are many alternative connections under this initiative (Pieriegud, 2016a). Poland is directly connected with the Northern Corridor (i.e., Trans-Siberian together with Central-Eurasian). It should also be noted that the transport corridors themselves operating under BRI are intended to be complementary to each other, not competitive but this is a purely Chinese perspective, in fact individual corridors and participating countries will largely compete with each other for the largest volume of goods flows.

The fact is that Poland has a very favorable geographical location - the Polish-Belarusian border may be the last westernmost key point for BRI, because it is one of the four main customs points for the whole initiative, next to the Chinese-Russian, Mongolian-Russian and Chinese-Kazakh borders (Hanusik \& Woźnica, 2020). In fact, however, virtually no country on the Eurasian continent has so-called undisputed transit facilities, as there are at least several alternative routes for individual transport routes (Pieriegud, 2016b). That situation means that the geographical location of Poland is no longer a clear guarantee 
of success. Appropriate infrastructure development and the construction of new and modernization of existing logistics centers are necessary. It should also be noted that the BRI concept seems to be gradually overlooked, both in the case of strategic plans and investment decisions. For example, Poland received around $€ 10$ billion in EU funds under the 2014-2020 Development Strategy, but most of them focused on the north-south rail connections (Lobyrev, Tikhomirov, Tsukarev, \& Vinokurov, 2018) and road transport infrastructure. Poland's membership in $17+1$ mechanism, which is focused on economic cooperation between China and the countries of Central and Eastern Europe (CEE) may be an opportunity for Poland's development. Membership in the $17+1$ group of countries can contribute to both easier acquisition of Chinese investment capital and to the increase in trade with the Middle Kingdom itself - over the past years, trade between China and the countries of Central and Eastern Europe has grown much faster than trade between China and the whole European Union (Brînză, 2020a).

Another problem for the BRI development may be the interests of other world powers. In the U.S., a debate is still on as to whether it is possible to include this initiative in the sphere of American interests or should the New Silk Road project be prevented (Shenin, 2018). Russia is another country that can shape the Belt and Road Initiative to a large extent. It shares over 4,000 km long border with China and can be the main transit country for the New Silk Road by direct connection with European countries. Russia seems skeptical about the Chinese project, but in 2015 a declaration was signed on coordinating the projects with emphasis on compatibility and complementarity of the projects, which potentially protects BRI from being blocked by Russia (Simola, 2016). Furthermore, the European Union itself will be of great importance for the BRI development, as it is the main destination for Chinese goods. Despite this importance, the EU does not seem to be practically focused on this initiative (Pavlićević, 2018). However, China is unlikely to treat the European Union as a potential partner - the goal is bilateral contacts with individual states, which may lead to conflicts between members of European Union in the future.

It should also be noted that the scope of this initiative and its geographical range are constantly changing, as China establishes economic relations with other countries. Nevertheless, the analysis of the role of Poland in BRI that has been carried out in the paper should remain valid despite potential changes. 


\section{Research methodology}

This paper has been developed as a result of research conducted under the project "Railway for Poland", which is implemented by a research group associated with the Polish Supply Management Leaders Nonprofit Association (Polish Supply Management Leaders, 2020). The analysis carried out for the needs of the paper was based on desk research and qualitative research.

Desk research included both strictly scientific sources and articles created by people associated with BIR. Qualitative research consisted of interviewing experts in supply chain management, logistics and international relations as well as experts and representatives of companies pursuing their activities on the New Silk Road. In total, six interviews were conducted, between June 12, 2020 and June 21, 2020. The main purpose of the interviews was to identify potential scenarios for the route of the New Silk Road transport corridor, which may run through Poland. Based on the interviews, the strengths and weaknesses as well as opportunities and threats for Poland's participation in this project were also determined. A detailed description of the interviews conducted is included in Annex 1. Information collected from interviews and desk research was synthesized and presented in this paper.

The empirical part of the paper contains an analysis of various scenarios of BIR in the geographical region in which Poland is located. The following situations have been identified:

1. Poland as a European hub.

2. Alternatives for Poland as a European hub - transit only.

3. Alternatives for Poland as a European hub - southern road.

4. Alternatives for Poland as a European hub - ro-ro neighbors.

The paper sums up with the SWOT analysis, where conclusions of the study are presented. The conducted analysis was based on desk research and interviews with experts. It should be emphasized that the standard SWOT analysis used in papers is a purely qualitative method, which allows only the identification of external and internal factors affecting Poland's role in BIR, without determining the significance of individual factors (Shinno, Yoshioka, Marpaung, \& Hachiga, 2006). 


\section{Research findings}

\subsection{Poland as a European hub}

The number of potential gate entries to the European Union that can be used by BRI is relatively small. The geographical location of Poland is a definite advantage of this country. It is therefore possible for Poland to become the main distribution center for the Northern Corridor. The discussed situation is presented in Figure 1.

Figure 1. Scenario for Poland as a European hub

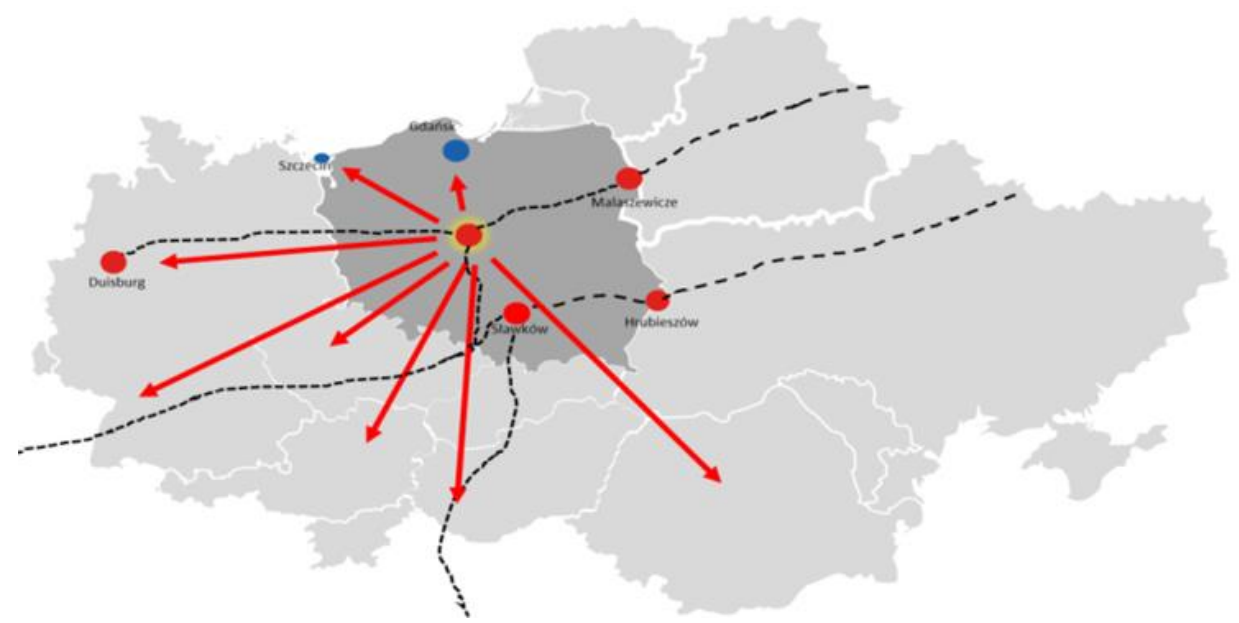

Source: Authors' own elaboration.

The situation presented above brings a great opportunity for the logistics industry and may also contribute to an increase in revenues generated by import duties. Companies from Central Europe may get a chance to compete for a share in the logistics services market. However, a significant proportion of them can be managed by global logistics operators. Moreover, virtually all revenues related to the organization of import transports mostly go to Chinese companies, which usually act as intermodal operators. Nevertheless, export orders, comprehensive logistics services or infrastructure sharing can be a chance for Polish logistics forms; having said that it should be noted that the quality of logistics service is one of the main factors determining the position of a given logistics company. Customer requirements are constantly increasing and undergoing significant changes, which means that logistics companies must respond quickly 
and introduce innovative solutions (Dziekoński \& Chwiećko, 2012). Therefore, the key issue of Poland's logistic activities (both those implemented by private enterprises as well as by local and central authorities) should be focused on increasing the Logistics Performance Index. Key indicators (KPIs) affecting the increase of Logistics Performance Index include:

- customs,

- infrastructure,

- tracking and tracing,

- ease of international shipments,

- logistics services quality,

- timeliness (The World Bank, 2018).

However, despite a very good geographical location, the value of the Logistics Index for Poland is disproportionately low in relation to potential possibilities - Poland ranks $31^{\text {st }}$ (The World Bank, n.d.). What is more, even in official strategic documents there is no reference to Poland's role in BRI - a good example is Strategy for Responsible Development for the period up to 2020 (including the perspective up to 2030), in which BRI is not mentioned (Ministerstwo Funduszy i Polityki Regionalnej [Ministry of Development Funds and Regional Policy], 2017).

Poland seems to be a very natural place to create a logistics hub for goods transported under the Belt and Road Initiative. Furthermore, the location itself may prove to be an insufficient asset. The potential benefits associated with performing the role of European Gate Hub are so large that many countries undertake or will probably take actions in the global supply chain in the future - sample scenarios describing alternative routes are presented later in the paper.

\subsection{Alternatives for Poland as a European hub - transit only}

A situation in which Poland will be treated as a strictly transit country may be a great threat to this state. Trains could be initially serviced in Poland, which mainly concerns the change of the rail spacing from $1520 \mathrm{~mm}$ to $1435 \mathrm{~mm}$ - the possibility of container reloading in Małaszewicze or Sławków or the use of automatic wheel change systems, e.g., SUW 2000 system (Graff, 2016), while the main logistics operations and their further distribution will be carried out in another country (probably a German port in Duisburg). The discussed situation is presented in Figure 2. 
Figure 2. Scenario for Poland - transit only

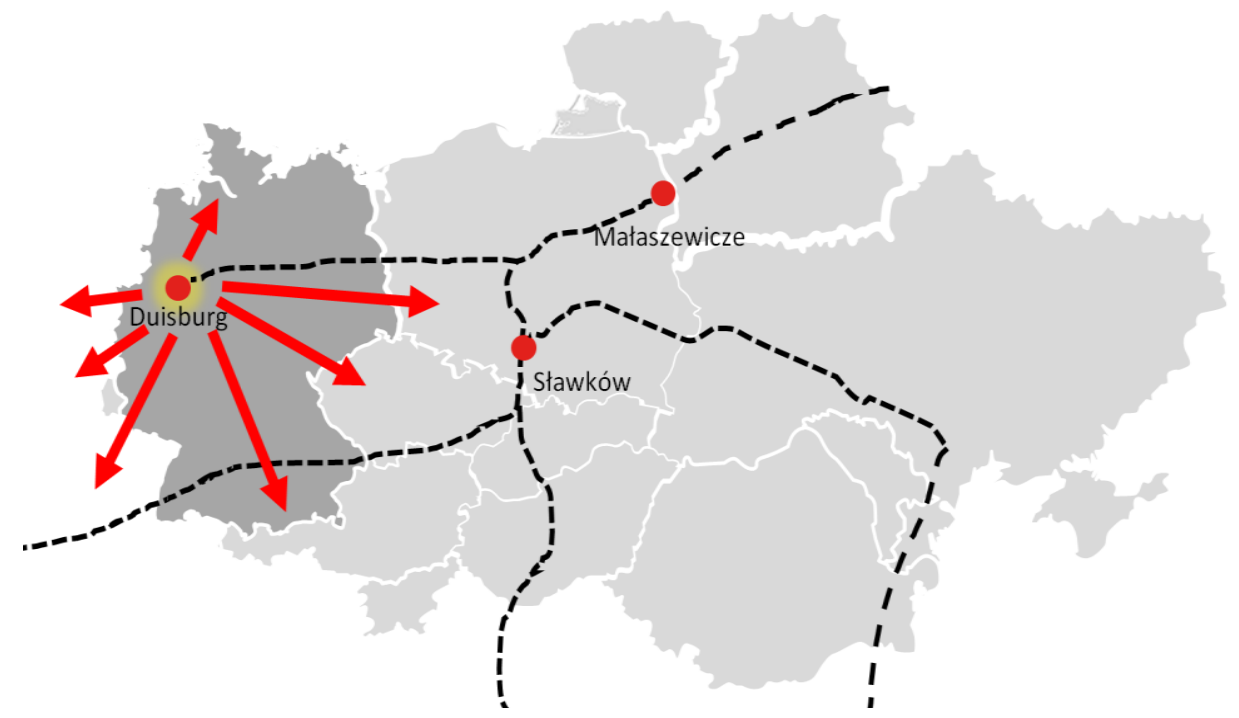

Source: Authors' own elaboration.

A situation in which the goods will only transit through Poland and all logistics operations will be handled in Duisport is very likely. Duisburg has a very good geographical location, from which distribution to other European markets is relatively simple. What is more, Duisport has a very developed logistics base - it is the largest river port in the world. Furthermore, about $30 \%$ of all rail transport between China and Europe is just passing through the port of Duisburg - there are 35 to 40 trains a week, and in the future their number is expected to increase up to 100 a week. What is more, the inland port and its gate terminal allow to operate about 850000 TEU annually (Brzozowski, 2019). Therefore, it is a very big threat to the Polish position in BRI - even a paradox may appear, in which goods intended for Polish market will be served in Duisburg and send back to Poland. That situation could have a negative impact on Polish economy.

However, the scenario in which Poland is treated only as a transit country still allows for achieving certain benefits. The potential profit for the economy is related to crossing the European customs border - a quarter of the revenues from tariffs will be transferred to the budget of the province in which the center serving customs formalities is located (Jakóbowski, Popławski, \& Kaczmarski, 2018). This means that the investment in logistics centers will be beneficial even if Poland is treated as a transit country - nevertheless, the benefits achieved in this way will be many times lower than in the case of comprehensive cargo handling in Polish logistics centers. 


\subsection{Alternatives for Poland as a European hub - southern road}

It is possible that the main BRI's corridor will bypass Poland. The reason may be, for example, greater activity of neighboring countries' authorities. One of the big threats may be the so-called southern road, which is presented in Figure 3.

Figure 3. Scenario for Poland - southern road

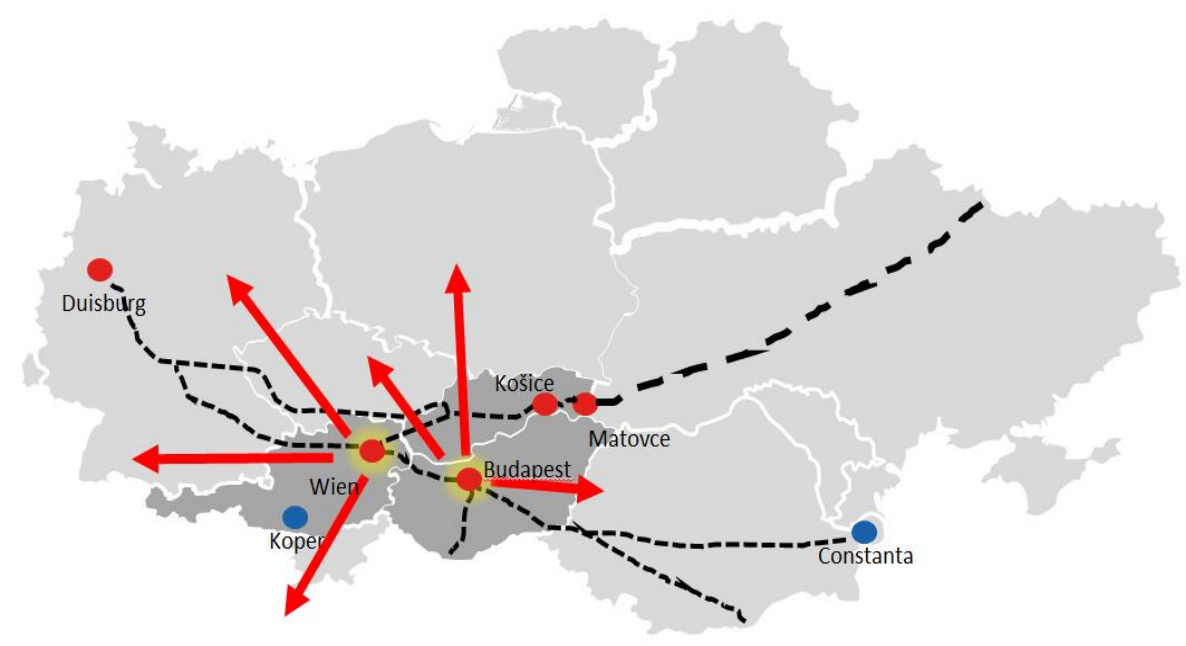

Source: Authors' own elaboration.

The 'southern road' consists of two potentially competitive solutions:

1. Slovakia-Austria corridor - Poland is not the only country on the border of the European Union. Slovakia, which like Poland has a $1520 \mathrm{~mm}$ rail track, can be a great threat. Currently, this line ends in Košice, but it is planned to extend it to Vienna - the planned completion date of this investment is 2033 (Reconnecting Asia, 2020). Such situation may pose a serious threat to Poland's position in BRI.

2. Corridor $X$ - the construction of a railway connection between Serbia and Hungary (Brînză, 2020b), currently blocked by the European Union, may cause the transfer of significance from Poland to Corridor X. Hungary may prove to be a very good distribution point for Central and Eastern Europe (also in the case of direct connection with Ukraine). The direct connection with the port of Piraeus also speaks for the strength of this solution. 


\subsection{Alternatives for Poland as a European hub - northern road (ro-ro neighbors)}

Other Baltic ro-ro seaports may also be a big threat to Poland. Such a situation may result in the transfer of some of the cargo from rail to sea transport Poland will virtually not benefit from such a situation. The described case is presented in Figure 4.

Figure 4. Scenario for Poland - northern road (ro-ro neighbors)

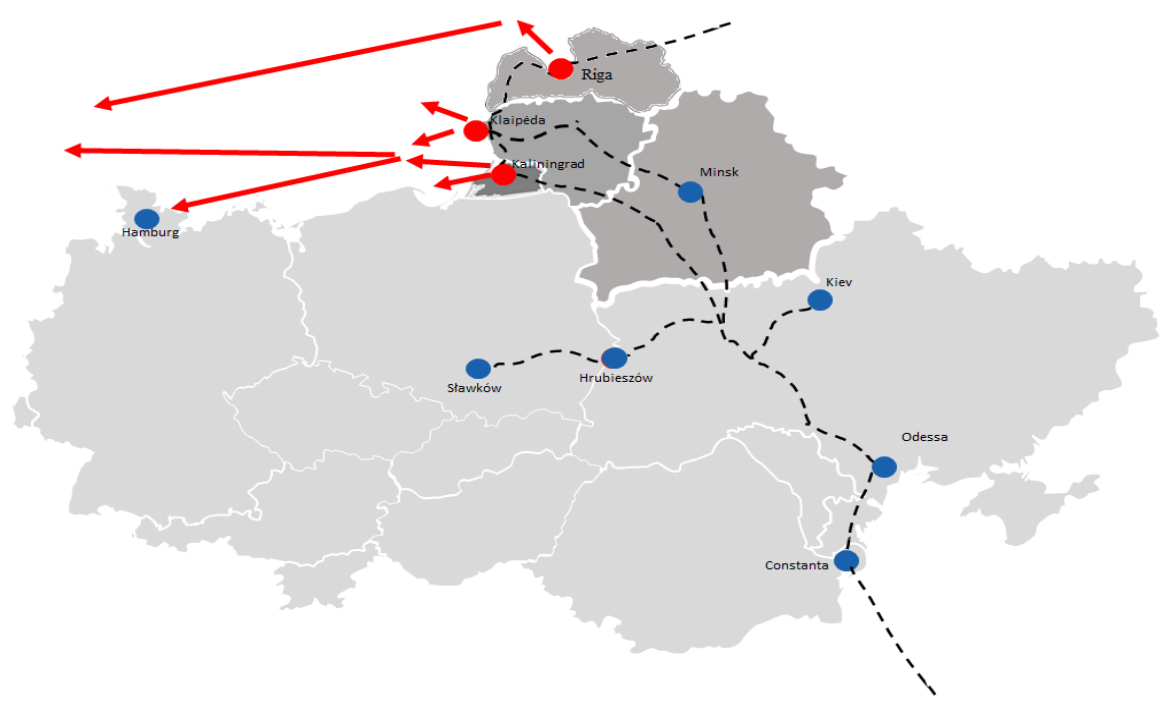

Source: Authors' own elaboration.

The presented alternative is significant because a large part of the ports in question have a rail connection with a $1520 \mathrm{~mm}$ rail spacing, which reduces the necessity of transshipment. Kaliningrad, Klaipeda or Riga may prove to be important ro-ro terminals. The role of the Baltic ports will largely depend on Russia's decision, e.g., redirecting cargo flows from the Central Corridor to the mentioned ports. Moreover, the Ukrainian vision of BRI practically bypasses Poland in favor of these ports. However, a very turbulent situation in Ukraine is related to the limitation of Chinese activity in that region. The Ukrainian conflict may prove to be a great opportunity to increase Poland's role in BRI - probability of increasing the role of transport via Belarus to the terminal in Małaszewicze, while limiting the role of Slovakia and Austria. 
The Scandinavian Peninsula countries may be another threat. The importance of trade with northern countries for China and their links with BRI were highlighted in the January 2018 Arctic White Paper (The State Council Information Office of the People's Republic of China, 2018). The document confirms that China is seeking to deepen cooperation with 'Arctic entities' under the BRI initiative. Numerous infrastructure projects have been created, including the deep port in Arkhangelsk and the Belkomur rail link connecting the White Sea with the Urals region, the Hålogaland bridge in Norway connecting the Narvik region with Øyjord (near Tromsø and the northern border of Sweden), the Helsinki-Tallinn tunnel and the Kirkenes rail link - Rovaniemi. Furthermore, Russia will probably continue to be the focal point of many China's BRI plans, but Finland is quickly becoming another important logistics modal point (Over the Circle, 2019). The Finnish road may prove to be a significant competitor for Poland as a BRI's gateway to the EU. The implementation of the hub-feeder model may be likely, where Finland as the main hub will strive to take over cargo from ports such as Kaliningrad, Klaipeda or Riga. It is also worth noting that virtually the entire Finnish railway network is based on a $1524 \mathrm{~mm}$ rail spacing.

\subsection{SWOT analysis for Poland as a European hub}

The chapter contains a SWOT analysis for Poland, which presents the conditions that may affect the role of Poland in Belt and Road Imitative in a synthetic way. The obtained results are presented in Table 1 .

Table 1. SWOT analysis for Poland's role in Belt and Road Initiative

\begin{tabular}{|l|l|}
\hline \multicolumn{1}{|c|}{ Strengths } & \multicolumn{1}{c|}{ Weaknesses } \\
\hline $\begin{array}{l}\text { 1. Good geographical location - a gateway to } \\
\text { Europe. }\end{array}$ & $\begin{array}{l}\text { 1. There are no authorities' strategies regarding } \\
\text { participation in BRI. }\end{array}$ \\
$\begin{array}{l}\text { 2. A large part of freight transported under BRI } \\
\text { is currently passing through Poland (mainly }\end{array}$ & $\begin{array}{l}\text { 2. A poorly developed, non-modern railway. } \\
\text { 3ałaszewicze). Chinese investment projects implemented } \\
\text { in Poland practically do not concern railways } \\
\text { 3. Strong logistics sector. } \\
\begin{array}{l}\text { 4. Current rail connections between China and } \\
\text { Poland (e.g., regular Chengdu connection to Lódź } \\
\text { or the first trains from Xi'an to Sławków) }\end{array} \\
\text { implemented in neighboring countries largely } \\
\text { emphasize them (e.g., planned intermodal } \\
\text { terminals in Košice, Leopoldov or Bratislava) }\end{array}$ \\
\hline
\end{tabular}


Table 1 cont.

\begin{tabular}{|c|c|}
\hline Opportunities & Threats \\
\hline $\begin{array}{l}\text { 1. The conflict in Ukraine may result in the } \\
\text { redirection of more loads to Belarus - } \\
\text { an opportunity for Małaszewicze. } \\
\text { 2. European Union blocking Chinese investments in } \\
\text { member countries (e.g., Serbia-Hungary railways). } \\
\text { 3. The Northern Corridor (Trans-Siberian and } \\
\text { Central-Eurasian), on which route lies Poland is } \\
\text { the shortest route, the fastest transport time, the } \\
\text { least number of reloading and customs operations }\end{array}$ & $\begin{array}{l}\text { 1. Strengthening the alliance with the U.S. } \\
\text { may lead to marginalization or even blocking BRI. } \\
\text { 2. Cargo taking over at the Port of Duisburg. } \\
\text { 3. Extending the wide track from Košice to Vienna. } \\
\text { 4. Hungary's efforts to create a logistics hub on their } \\
\text { territory. } \\
\text { 5. Adjoining countries with ro-ro terminals seaports. } \\
\text { 6. Asymmetry of goods flows between China and } \\
\text { the European Union }\end{array}$ \\
\hline
\end{tabular}

Source: Authors' own elaboration.

The analysis carried out in the chapter allows the determination of the potential possibilities of the New Silk Road in the geographical region in which Poland is located. Poland has a number of advantages, but they can be largely obscured by weaknesses and threats. The main conclusion from the conducted research is the fact that Poland, in the absence of coordinated actions, may lose its position in BRI significantly.

\section{Discussion}

The various alternatives of the New Silk Road route define the final role of Poland in this project to a different extent. As of the day of writing this study, Poland plays a dominant role in cargo handling under BRI. Nevertheless, a number of activities undertaken by the neighboring countries may significantly limit the importance of Poland in this initiative. Therefore, it is necessary to take actions aimed at strengthening the importance of Poland in the New Silk Road.

Among the alternative options to Poland as a European hub, the transit only option can be considered as the most advantageous. In this case, Poland does not profit from the logistic service of cargo, but it is still the main entity introducing cargo into the territory of the European Union. Thus handling most of the customs formalities. Such situation, despite the fact that Poland's role has significantly diminished, still allows for some economic benefits.

All variants bypassing Poland are definitely worse alternatives. Furthermore, these variants will function parallel to the corridor passing directly through Poland. All activities of Poland should therefore be focused on increasing the attractiveness of this country on the international arena, which will allow 
for limiting losses to third countries. Therefore, a number of actions should be taken that will contribute to the increase of Poland's role in BRI, as Poland's current strengths may prove to be insufficient to fulfill the role of a European hub gate for BRI in the future. Additionally, western countries also aspire to such a role. However, due to geographical issues, western consolidation and deconsolidation points should not cover the countries and regions located to the east or south-east of Europe, which can be considered an additional opportunity for Poland.

Furthermore, in the case of the BRI project, one cannot escape from aspects related to broadly understood geopolitics. These conditions are not discussed in this paper in more detail, but there are at least two additional main challenges:

1. The risk of becoming dependent on China - investments and subsidies from China may lead to serious debts and thus put pressure on Polish political and economic behavior in the future.

2. Negative attitude to the U.S. administration's BRI project - the USA is one of Poland's most important allies, and at the same time has increasingly tense relations with China. This means that various political pressures from the American administration must be taken into account.

It is also worthwhile to specify that developing specific actions leading to the increase in Poland's competitive strength is already an ambitious undertaking, but it should not be an end in itself. It should be much more important to take up professional and wide-ranging activities, both at the level of private enterprises and public administration, that lead to the improvement of overall Polish logistics condition.

\section{Conclusions}

\subsection{Research contribution}

The conducted research takes a new look at the subject of the New Silk Road, including the role of Poland in this initiative. In the opinion of the authors, there have been no studies in the literature dealing with similar topics so far, which makes it impossible to compare the obtained results of the analysis with other research works. Some of the scenarios presented in the paper may have been published in other works, however, the authors did not find a comprehensive study that would take up the topic in question - the conclusions regarding the role of Poland in the New Silk Road initiative and the importance of the Northern Corridor seem to coincide with other studies in this field. 
The conducted research led to the attainment of the main goal of the paper, i.e., determining the role of Poland in Belt and Road Initiative. The obtained results also provided answers to both research questions - Poland definitely has a number of advantages that allow it to aspire to the role of a European hub gate for BRI (e.g., a very convenient geographical location, developed logistics facilities, or extensive use of Małaszewicze as the main customs gate to the European Union). Nevertheless, there are a number of alternative routes that partially or even completely bypass Poland's territory (transit only, southern and northern road - these routes were described in detail and their characteristics were given). As with the results of the research carried out, the role of Poland in the New Silk Road initiative may be related to the handling of the main cargo flows, which will contribute to significant economic growth. However, there is also a good chance that this project will completely or partially bypass Poland. Therefore, it is necessary to take a number of actions on the part of Poland, which would be aimed at strengthening its position in the project of the New Silk Road. These activities should be primarily associated with the development of infrastructure, support for the logistics sector and including BRI in main strategic documents. Staying passive will probably cause Poland to be excluded from the key role in BRI.

The paper also contains a synthesis of the results obtained in the form of a SWOT matrix, which organizes the results of the tests carried out and provides a kind of summary of the entire analysis. As it was mentioned, Poland's strength is its geographical location. The main weakness is the ambiguous and often contradictory actions of the state authorities. One of the most important threats may turn out to be the actions of other countries, which are also striving to strengthen their position on the New Silk Road and take over some goods flow that have so far been served by Poland. The actions of the European Union, which may effectively limit Chinese investments in the New Silk Road, are also an important element. On the one hand, this is a threat to potential investments carried out in Poland, and on the other, it should be noted that this blocking applies not only to Poland, and the potential actions of the European Union may also delay or even completely prevent some investment projects in other countries (e.g., Hungary), which may turn out to be an opportunity for Poland. 


\subsection{Research implication}

The conducted research clearly showed the current position of Poland on the New Silk Road and defined the main development barriers for this concept. The alternative options for the route of the New Silk Road identified in the study may be used to create a development strategy, both from the perspective of private sector entities and public administration. Furthermore, the presented paper may become an impulse for an extended academic debate and constitute the basis for further research. The statements contained in the paper can be used both as a basis for further research and help implement managerial tasks in entities related to international logistics.

The obtained research results can be used to create an action strategy of entities related to the activities lobbying the interests of the Polish logistics sector on the New Silk Road. The indication of alternative routes of the New Silk Road can be used to determine further actions, both for the private sector and public administration.

\subsection{Research limitation and future works}

One of the basic limitations of this study is the constantly changing global political and economic situation as well as the lack of a clear position of the Polish authorities regarding this project. Furthermore, despite the fact that the article refers to the role of Poland in the New Silk Road project, its potential alternatives can be considered a universal knowledge base for entities interested in this subject.

Nevertheless, this paper is a precise attempt to determine Poland's potential role in BRI. Future research should primarily cover the activities of the Polish logistics sector and those at the level of regional and central authorities. In order to determine the economics of individual options, and thus also the possibility of their implementation in the future, it would be useful to develop an econometric model taking into account the various alternatives of the Northern Corridor and to determine the most effective way. 


\section{References}

Brînză, A. (2020a). The "17+1" mechanism. Caught between China and the United States. China Quarterly of International Strategic Studies, 5(2), 213-216. https:// doi.org/10.1142/S237774001950009X

Brînză, A. (2020b, April). China and the Budapest-Belgrade railway saga. The Diplomat. Retrieved from https://thediplomat.com/2020/04/china-and-the-budapest-belgraderailway-saga/

Brzozowski, A. (2019). W Duisburgu powstanie największy terminal w Europie [The largest terminal in Europe will be built in Duisburg]. Retrieved from https:// portaltsl.pl/logistyka/w-duisburgu-powstanie-najwiekszy-terminal-w-europie/

Cai, P. (2017). Understanding China's Belt and Road Initiative. Sydney: Lowy Institute. Retrieved from https://think-asia.org/handle/11540/6810

Choroś-Mrozowska, D. (2019). The Chinese Belt and Road Initiative from the Polish perspective. Comparative Economic Research. Central and Eastern Europe, 22(2), 39-53. https://doi.org/10.2478/cer-2019-0011

Dziekoński, K., \& Chwiećko, J. (2012). Innowacyjność przedsiębiorstw z branży TSL [Innovativness of enterpises within TSL branch]. Ekonomia $i$ Zarzadzanie, 5(2), 176-193. https://doi.org/10.12846/j.em.2013.02.11

Garcia-Herrero, A., \& Jianwei, X. (2017). China's Belt and Road initiative: Can Europe expect trade gains? China and World Economy, 25(6), 84-99. https://doi.org/ 10.1111/cwe. 12222

Graff, M. (2016). System SUW 2000 w komunikacji przestawczej 1435/1520 mm [SUW 2000 system in the pivot communication 1435/1520 mm]. Technika Transportu Szynowego, 1-2, 34-53. Retrieved from https://docplayer.pl/20285714-System-suw2000-w-komunikacji-przestawczej-1-435-1-520-mm-technika-marek-graff.html

Hanusik, A., \& Woźnica, A. (2020). Potential impact of SARS-COV-2 on Belt and Road Initiative. In: W. Szkutnik, A. Sączewska-Piotrowska, M. Hadaś-Dyduch, J. Acedański (Eds.), 14th International Scientific Conference "Analysis of International Relations 2020. Methods and Models of Regional Development. Summer Edition”. Conference Proceedings (pp. 97-107). Katowice: Publishing House of the University of Economics in Katowice

Hughes, A., Lechner, A., Chotov, A., Horstmann, A., Hinsley, A., Tritto, A., Chariton, A., Li, B., Ganapin, D., Simonow, E., Morton, K., Toktomushev, K., Foggin, M., Tan-Mullins, M., Orr, M., Griffiths, R., Nash, R., Perkin, S., Glemet, R., Kim, M., $\& \mathrm{Yu}$, D. (2020). Horizon Scan of the Belt and Road Initiative. Trends in Ecology \& Evolution, 35(7), 583-593, https://doi.org/10.1016/j.tree.2020.02.005

Jakóbowski, J., Popławski, K., \& Kaczmarski, M. (2018). The Silk Railroad. The EU-China rail connections: Background, actors, interests (OSW Studies, No. 72). Warsaw: Centre for Eastern Studies. Retrieved from https://www.osw.waw.pl/ sites/default/files/studies_72_silk-railroad_net.pdf

Kuzmina, E. E., \& Mair, V. H. (Eds.). (2008). The prehistory of the Silk Road. Philadelphia: University of Pennsylvania Press. 
Lei, Y. (2018, June). US attitude toward BRI critical to relations. Global Times. Retrieved from http://www.globaltimes.cn/content/1106845.shtml

Lobyrev, V., Tikhomirov, A., Tsukarev, T., \& Vinokurov, E. (2018). Belt and Road transport corridors: Barriers and investments (Report No. 50). Sankt Petersburg: Eurasian Development Bank Centre for Integration Studies. Retrieved from https://reconasia-production.s3.amazonaws.com/media/filer_public/2d/2e/2d2e04 50-8787-43ad-8b9d-b10ef394d512/edb.pdf

Ministerstwo Funduszy i Polityki Regionalnej [Ministry of Development Funds and Regional Policy]. (2017). Strategia na rzecz Odpowiedzialnego Rozwoju do roku 2020 (z perspektywa do 2030 r.) [Strategy for Responsible Development for the period up to 2020 (including the perspective up to 2030)]. Retrieved from https:// www.gov.pl/web/fundusze-regiony/informacje-o-strategii-na-rzecz-odpowiedzialnego -rozwoju

Murton, G., \& Lord, A. (2020). Trans-Himalayan power corridors: Infrastructural politics and China's Belt and Road Initiative in Nepal. Political Geography, 77, https:// doi.org/10.1016/j.polgeo.2019.102100

Over the Circus. (2019). China and Finland: The ice road cometh? Retrieved from https://overthecircle.com/2019/03/17/china-and-finland-the-ice-road-cometh/

Pavlićević, D. (2018). China, the EU and One Belt, One Road strategy. China Brief, 15(15). Retrieved from https://jamestown.org/program/china-the-eu-and-one-beltone-road-strategy/

Pieriegud, J. (2016a, March-April). Nowy Stary Szlak Jedwabny a Polska [The New Old Silk Road and Poland]. Kurier Kolejowy 3-4/2016, 4

Pieriegud, J. (2016b, March-April). Nowy Szlak Jedwabny, Polska a intermodal [The New Silk Road, Poland and intermodal]. Kurier Kolejowy, 3-4, 22-24

Polish Supply Management Leaders. (2020). Retrieved from https://psml.pl/

Polish Supply Management Leader. (2021). Kolej na Polske [Railway for Poland]. Retrieved from https://psml.pl/programy/kolej-na-polske/

Prodi, G., \& Fardella, E. (2018). The Belt and Road Initiative and its impact on Europe (Valdai Papers, No. 82). Moscow: Valdai Discussion Club. Retrieved from https:// valdaiclub.com/files/17415/

Reconnecting Asia. (2020). Kosice-Vienna Railway (Construction). Retrieved from https://reconnectingasia.csis.org/database/projects/kosice-vienna-railway-construction /3b92029a-1f75-402a-adf5-8d9cf7b3786e/

Shenin, S. (2018). "The Silk Road" of the 21st Century: Debate in the USA. Mirovaya ekonomika i mezhdunarodnye otnosheniya, 62(9), 60-70. https://doi.org/10.20542/ 0131-2227-2018-62-9-60-70

Shinno, H., Yoshioka, H., Marpaung, S., \& Hachiga, S. (2006). Quantitative SWOT analysis on global competitiveness of machine tool industry. Journal of Engineering Design, 17(3), 251-258. https://doi.org/10.1080/09544820500275180 
Simola, H. (2016). Economic relations between Russia and China - increasing interdependency? BOFIT Policy Brief, 6, 14-19. Retrieved from https://helda.helsinki. fi/bof/bitstream/handle/123456789/14346/bpb0616.pdf?sequenc

Summers, T. (2020). Structural power and the financing of the Belt and Road Initiative. Euroasian Geography and Economics, 61, 146-151. https://doi.org/10.1080/1538 7216.2020.1715234

The State Council Information Office of the People's Republic of China. (2018). China's Arctic policy. Retrieved from http://english.www.gov.cn/archive/white_paper/ 2018/01/26/content_281476026660336.htm

The World Bank. (n.d.). Aggregated LPI 2012-2018. Retrieved from https://lpi. worldbank.org/international/aggregated-ranking

The World Bank. (2018). How countries stack up. Retrieved from https://lpi. worldbank.org/sites/default/files/LPI-infographic-2018-780.png

Tuttle, E. (2019). From Silk Road to Silicon Road, How the Belt and Road Initiative will transform the global economy. Retrieved https://www.ciob.org/blog/silk-roadsilicon-road-how-belt-and-road-initiative-will-transform-global-economy

Wang, C., Lim, M. K., Zhang, X., Zhao, L., \& Lee, P. T. (2020, April). Railway and road infrastructure in the Belt and Road Initiative countries: Estimating the impact of transport infrastructure on economic growth. Transportation Research Part A: Policy and Practice, 134, 288-290. https://doi.org/10.1016/j.tra.2020.02.009

\section{Appendix 1. Interviews with experts, questions, and sample answers}

\begin{tabular}{|c|c|c|}
\hline No. & Issue & Detail \\
\hline 1 & 2 & 3 \\
\hline 1 & $\begin{array}{l}\text { Aim of } \\
\text { interview }\end{array}$ & $\begin{array}{l}\text { The aim of the interview was to define the role of Poland in the Belt and Road } \\
\text { Initiative (BRI) and potential alternative routes to this concept }\end{array}$ \\
\hline 2 & $\begin{array}{l}\text { Interview } \\
\text { manner }\end{array}$ & $\begin{array}{l}\text { Due to the coronavirus pandemic the interviews were conducted over the phone } \\
\text { or using instant Messenger. One invited expert and one of the authors of the paper } \\
\text { participated in each interview. Each conversation was divided into two parts. The } \\
\text { first concerned the main assumptions of the New Silk Road (which was used to } \\
\text { create another paper), the second was directly related to the issue of the Polish role } \\
\text { in this initiative and potential alternative routes. Each part lasted about } 15 \text { minutes. } \\
\text { The calls were not recorded }\end{array}$ \\
\hline 3 & $\begin{array}{l}\text { Interviews } \\
\text { with experts } \\
\text { and dates }\end{array}$ & $\begin{array}{l}\text { 1. Managing director of a logistics operator in Central and Eastern Europe, } \\
\text { June } 12,2020 . \\
\text { 2. Member of the board of an association of logistics managers, June } 12,2020 . \\
\text { 3. Transport economist, Habilitated Doctor in economic sciences, University } \\
\text { of Economics in Katowice, June } 13,2020 . \\
\text { 4. Member of the project team associated with the Polish logistics sector on the } \\
\text { New Silk Road, June } 16,2020 . \\
\text { 5. President of the Board in an international shipping company, June } 20,2020 . \\
\text { 6. Strategy \& innovation expert, specialist in the field of transportation, partner } \\
\text { of consulting firm. June } 21,2020\end{array}$ \\
\hline
\end{tabular}




\begin{tabular}{|c|c|c|}
\hline 1 & 2 & 3 \\
\hline 4 & $\begin{array}{l}\text { Non- } \\
\text { participation }\end{array}$ & All people invited to the study took part in it \\
\hline 5 & $\begin{array}{l}\text { Research team } \\
\text { personal } \\
\text { characteristics }\end{array}$ & $\begin{array}{l}\text { 1. Andrzej Hanusik - male, Master's degree in Engineering, University } \\
\text { of Economics in Katowice, research and teaching assistant, member of the research } \\
\text { team in the Department of Transport, member of the "Kolej na Polskę" project. } \\
\text { 2. Anna Woźnica - female, Master's degree in Engineering, University of Economics } \\
\text { in Katowice, research and teaching assistant, member of the research team in the } \\
\text { Department of Transport and member of the "Kolej na Polskę" project }\end{array}$ \\
\hline 6 & $\begin{array}{l}\text { Relations } \\
\text { with experts }\end{array}$ & $\begin{array}{l}\text { Experts number 1, 5, } 6 \text { were not known previously by the authors. The authors } \\
\text { co-operated with experts number 2,3,4. Each interview began with the presentation of } \\
\text { people carrying out the research and the purposes for which the interview will be used }\end{array}$ \\
\hline 7 & Sampling & $\begin{array}{l}\text { Half of the respondents were directly selected by the researchers (co-operation } \\
\text { as part of a business project), the other half were recommended by experts }\end{array}$ \\
\hline 8 & $\begin{array}{l}\text { Description } \\
\text { of sample }\end{array}$ & $\begin{array}{l}\text { People selected for the research sample have many years of experience in the } \\
\text { logistics industry and are directly involved in the New Silk Road project }\end{array}$ \\
\hline 9 & $\begin{array}{l}\text { Methodological } \\
\text { orientation and } \\
\text { data collection }\end{array}$ & $\begin{array}{l}\text { Experts were directly asked about the problems raised in the paper - their state- } \\
\text { ments were used to create the empirical part of the paper. The interlocutors were } \\
\text { previously informed about the topics discussed during the interview. Interviews } \\
\text { with each person were conducted once }\end{array}$ \\
\hline 10 & Data saturation & $\begin{array}{l}\text { Most of the statements referred to the same main issues. The responses differed } \\
\text { mainly in the respondents' individual approach to the issue of the New Silk Road }\end{array}$ \\
\hline 11 & Data coding & $\begin{array}{l}\text { The authors of the paper handled data recording. The basis for the empirical part of } \\
\text { the paper were notes made during the interviews. Those notes were not forwarded } \\
\text { to respondents for approval }\end{array}$ \\
\hline 12 & Data analysis & $\begin{array}{l}\text { Main topics were identified in advance. No specialized software was used to } \\
\text { analyze the data. Participants did not provide feedback on the findings }\end{array}$ \\
\hline 13 & $\begin{array}{l}\text { Interview } \\
\text { questions }\end{array}$ & $\begin{array}{l}\text { 1. Should Poland get involved in the New Silk Road? } \\
\text { 2. What are the strengths of Poland related to its active participation } \\
\text { in the New Silk Road? } \\
\text { 3. What are the weaknesses of Poland related to its active participation } \\
\text { in the New Silk Road? } \\
\text { 4. What are the main threats to the Polish position on the New Silk Road? }\end{array}$ \\
\hline 14 & $\begin{array}{l}\text { Interviews } \\
\text { findings }\end{array}$ & $\begin{array}{l}\text { All interviewees indicated that the New Silk Road should be considered one of the } \\
\text { main directions of development of Polish logistics. The main strength of Poland } \\
\text { was clearly considered to be a very favorable geographical location. The greatest } \\
\text { weakness was the lack of coordinated actions at the central level. According to the } \\
\text { interviewees, the main threats to Poland are the actions of other countries, such } \\
\text { as Germany, Slovakia, Austria, and the Baltic states }\end{array}$ \\
\hline 15 & $\begin{array}{l}\text { Sample inter- } \\
\text { view answers - } \\
\text { question } 1\end{array}$ & $\begin{array}{l}\text { 1. "As a country, we are not exceptionally rich, especially when we look at our } \\
\text { western neighbors. Thus, we cannot resign from participation in this initiative, } \\
\text { we simply cannot afford it." } \\
\text { 2. "Indisputably, China will do without Poland, we will not be able to do without } \\
\text { China." } \\
\text { 3. "The business practice has been the cooperation with the Chinese party for a long } \\
\text { time. The question should be whether the government should get more involved } \\
\text { and support practitioners. In my opinion, yes, or at least not to disturb them" }\end{array}$ \\
\hline
\end{tabular}




\begin{tabular}{|c|c|c|}
\hline 1 & 2 & 3 \\
\hline 16 & $\begin{array}{l}\text { Sample inter- } \\
\text { view answers - } \\
\text { question } 2\end{array}$ & $\begin{array}{l}\text { 1. "Our greatest asset is definitely our geographical location, where we can act as } \\
\text { a gateway to Europe for Chinese goods." } \\
\text { 2. "The main transport corridor runs through Poland, the remaining ones are } \\
\text { definitely less effective and treated as a remote alternative." } \\
\text { 3. "Poland for many years has been considered the transport hub of Europe, which } \\
\text { can definitely help us (regarding the New Silk Road - the author added)" }\end{array}$ \\
\hline 17 & $\begin{array}{l}\text { Sample inter- } \\
\text { view answers - } \\
\text { question } 3\end{array}$ & $\begin{array}{l}\text { 1. "The main problem is very ambivalent approach of the state administration to } \\
\text { the Chinese side - on the one hand, we have powerful economic benefits, } \\
\text { and on the other, the USA." } \\
\text { 2. "Probably the biggest barrier may turn out to be complicated, unclear and } \\
\text { unfriendly legal and tax regulations as well as insufficient customs facilities." } \\
\text { 3. "Deficiencies in railway, transshipment and port infrastructure as well as } \\
\text { weak emphasis on intermodal solutions" }\end{array}$ \\
\hline 18 & $\begin{array}{l}\text { Sample inter- } \\
\text { view answers - } \\
\text { question } 4\end{array}$ & $\begin{array}{l}\text { 1. "Definitely greater involvement of neighboring countries in this project, which } \\
\text { outclasses the passive approach of the Polish side." } \\
\text { 2. "Have a look what is happening around - Germany is investing in Duisburg, } \\
\text { Baltic ro-ro ports are expanding. Everyone thinks about BRI, but we don't." } \\
\text { 3. "Paradoxically, our geographic dividend may be our doom - we are pleased } \\
\text { with our location, the fact that most of the loads pass through our country. } \\
\text { But we are doing nothing to develop and the enemy is not sleeping. We rest on } \\
\text { our laurels and others are stealing this wreath from us. If this goes on, we will } \\
\text { wake up with nothing" }\end{array}$ \\
\hline
\end{tabular}

